\title{
Phenolics and carotenoids contents and radical scavenging capacity of some selected solanaceous medicinal plants
}

\author{
Rumana Islam, Md. Nesar Uddin, Md. Ashrafuzzaman, Md. Injamum-Ul-Hoque
}

Department of Crop Botany, Bangladesh Agricultural University, Mymensingh-2202, Bangladesh

\begin{tabular}{|c|c|}
\hline ARTICLE INFO & Abstract \\
\hline $\begin{array}{l}\text { Article history: } \\
\text { Received: } 26 \text { February } 2018 \\
\text { Accepted: } 11 \text { April } 2018 \\
\end{array}$ & $\begin{array}{l}\text { Plants being an important source of medicine play significant role in human health. The aim of the present } \\
\text { study was to evaluate the total phenolics and carotenoids contents, and free radical scavenging capacity of } \\
\text { leaves and fruits of selected five solanaceous medicinal plants, namely Solanum melongena (brinjal), } \\
\text { Solanum torvum (tit begun), Solanum virginianum (kantikari), Solanum sisymbrifolium (sada kantikari) }\end{array}$ \\
\hline $\begin{array}{l}\text { Keywords: } \\
\begin{array}{l}\text { Solanum, antioxidant, DPPH, } \\
\text { carotene }\end{array}\end{array}$ & $\begin{array}{l}\text { and Solanum nigrum (futi begun). Carotenoids content in the leaves and fruits of solanaceous plants varied } \\
\text { significantly among the species. Leaf phenolics content ranged between } 147.40 \text { (S. melongena) and } 585.15 \\
\text { (S. virginianum) mg gallic acid equivalent (GAE) } / 100 \mathrm{~g} \text { fresh weight, while fruit phenolics content varied } \\
\text { from } 50.52 \text { (S. nigrum) to } 105.02 \text { (S. virginianum) } \mathrm{mg} \mathrm{GAE} / 100 \mathrm{~g} \text { fresh weight. } \mathrm{IC}_{50} \text { values for scavenging }\end{array}$ \\
\hline $\begin{array}{l}\text { Correspondence: } \\
\text { Md. Nesar Uddin } \\
\text { (nesar.uddin@bau.edu.bd) }\end{array}$ & $\begin{array}{l}\text { 2, 2-diphenyl-1-picrylhydrazyl radical (DPPH) radical ranged between } 31.52(S . \text { nigrum) and } 33.55 \text { (S. } \\
\text { melongena) } \mathrm{mg} \mathrm{mL}^{-1} \text { in leaf, while in fruit it ranged between } 27.90 \text { (S. virginianum) and } 33.11 \text { (S. } \\
\text { melongena) } \mathrm{mg} \mathrm{mL}^{-1} \text {. The highest carotenoids content }\left(0.370 \mathrm{mg} \mathrm{g}^{-1} \text { fresh weight) was measured from }\right. \\
\text { Solanum nigrum leaf. S. virginianum leaf contained about } 4-\text { fold high phenolics content than that in } S \text {. } \\
\text { melongena. } S \text {. nigrum leaf had about } 15-\text { fold high carotenoids content }\left(0.370 \mathrm{mg} \mathrm{g}^{-1} \text { fresh weight). }\right. \\
\text { compared to } S \text {. torvum and } S \text {. virginianum fruits }\left(0.024 \mathrm{mg} \mathrm{g}^{-1} \mathrm{FW} \text { in each). Because of the highest fruit }\right. \\
\text { phenolics and carotenoids content along with the lowest } \mathrm{IC}_{50} \text { values for scavenging DPPH, } S \text {. virginianum } \\
\text { fruit can be considered as superior for its health beneficial biochemical constituents. }\end{array}$ \\
\hline
\end{tabular}

\section{Introduction}

Medicinal plants have been used in Ayurvedic, Unani and folk medicine since ancient times in Bangladesh. Even in the present day, use of medicinal plants in primary health care system is very important, especially in remote rural communities and poorly accessible areas.The family Solanaceae represents one of the most economically and medicinally important families of angiosperms. The genus Solanum is a hyper-diverse taxon of this family. There are about 2000 species of Solanum in the world that are mainly distributed in the tropical and sub-tropical areas, with a small number in the temperate areas (Jennifer and James,1997). Eggplant is one of the most common vegetables in Bangladesh. Wild species of Solanum have been extensively used in folk-medicine for their protective effects on the liver and anti-secretory gastric properties (Sabir and Rocha, 2008). S. torvum a wild ally of S. melongena with promising multidisease resistant traits has great economic, medicinal and genetic importance (Hao et al., 2015). It is an important medicinal plant in tropical and subtropical countries and is widely used like food and folk medicine around the world. Literatures shows that $S$. torvum is mainly used for the treatment of fever, wounds, tooth decay, reproductive problems and arterial hypertension (Jaiswal, 2012). S. nigrum has been extensively used for traditional medicine in India and other parts of world to cure liver disorder, chronic skin ailments, inflammatory conditions, painful periods, fevers, diarrhoea, eye disease, hydrophobia etc. (Saleem et al., 2009). S. virginianum used traditionally in cold, fever, migraine, headache, dental infections, cough, and pain in chest, reduces the pain and swelling in arthritis (Sundar and Pillai, 2016). S. sisymbrifolium is a densely prickled perennial shrub used to treat pain, inflammation. A number of compounds from the plant have already been reported to possess hypotensive activity (Gupta et al., 2014).

Sporadically some of these important medicinal plants have been studied separately by the scientists for their phenolics content, 2,2-diphenyl-1-picrylhydrazyl radical (DPPH) radical scavenging capacity and pigment content. In the present study these medicinal plants were taken to assess their total soluble phenolics, antioxidative power to scavenge free radical compounds and carotenoids content. This would provide a better understanding of their relative importance as natural antioxidants in the defense against oxidative stress. Keeping this view in mind laboratory studies were done to assess and compare total phenolics content in different medicinal plants; to determine radical scavenging ability of plant extracts as an index of antioxidative power of these plants against oxidative stress; and to quantify carotenoids content in these plant samples.

\section{Materials and Methods}

Plant materials and experimental sample collection Cultivated eggplant (Solanum melongena L.) and its four wild relatives, namely tit begun (Solanum torvum Sw.), 
significantly among the tested eggplant and its four wild relatives, and it ranged from 147.40 to $585.15 \mathrm{mg} \mathrm{GAE} /$ $100 \mathrm{~g}$ fresh weight. The highest amount of phenolic content was recorded in S. virginianum $(585.15 \mathrm{mg} / 100$ g FW) followed by S. torvum leaves $(510.511 \mathrm{mg} / 100 \mathrm{~g}$ $\mathrm{FW})$. The lowest amount of phenolic content was found in the leaves of S. melongena (147.399 mg/ $100 \mathrm{~g} \mathrm{FW})$. Phenolics contents in S. nigrum and S. sisymbrifolium were 163.07 and $187.63 \mathrm{mg} / 100 \mathrm{~g} \mathrm{FW}$, respectively. Considering the value of phenolics content in $S$. melongena leaves $(147.40 \mathrm{mg})$ as $100 \%$, the relative value of phenolics content in the leaves of $S$. virginianum, S. sisymbrifolium, S. torvum and S. nigrum were $397.0,127.3,346.4$ and $110.6 \%$, respectively.

Phenolics content in fruits of eggplant and its four wild relatives also varied significantly and ranged from 50.52 to $105.02 \mathrm{mg}$ GAE/ $100 \mathrm{~g}$ fresh weight (Fig. 1). Phenolics content was recorded maximum in $S$. virginianum fruits (105.02 mg GAE/100 g FW) followed by $S$. sisymbrifolium fruit ( $89.60 \mathrm{mg} \mathrm{GAE} / 100 \mathrm{~g} \mathrm{FW}$ ). The minimum amount of phenolics was found in the fruits of S. nigrum (50.52 mg GAE/100 g FW). Fruit of S. melongena and $S$. torvum contained phenolic 67.99 and $55.56 \mathrm{mg} \mathrm{GAE} / 100 \mathrm{~g} \mathrm{FW}$, respectively. Phenolics content in the fruit of $S$. torvum, S. virginianum, $S$. sisymbrifolium and S. nigrum were 81.7, 154.5, 131.8 and $74.3 \%$, respectively of that in S. melongena (67.99 $\mathrm{mg} \mathrm{GAE} / 100 \mathrm{~g} \mathrm{FW}$ ) treated as $100 \%$.

\section{DPPH radical scavenging capacity}

The $\mathrm{IC}_{50}$ value (the amount of antioxidant material required to scavenge $50 \%$ of free radical in the assay system) of leaf extract to scavenge DPPH radical varied significantly among the tested of Solanum spp. and ranged from 31.52 (Solanum nigrum) to 36.85 (Solanum torvum) $\mathrm{mg} \mathrm{mL}^{-1}$ leaf methanolic extract (Fig. 2). $S$. virginianum, $S$. sisymbrifolium and $S$. nigrum leaf extracts showed statistically the lowest $\mathrm{IC}_{50}$ values as $31.52, \quad 32.59$ and $31.52 \mathrm{mg} \mathrm{mL} \mathrm{m}^{-1}$ leaf extract, respectively and thus having highest radical scavenging capacity. Whereas Solanum torvum leaf extract exhibited the highest $\mathrm{IC}_{50}\left(36.85 \mathrm{mg} \mathrm{mL}^{-1}\right.$ leaf extract) and thus having the lowest radical scavenging capacity. Considering the $\mathrm{IC}_{50}$ value of $S$. melongena leaf (33.10 $\mathrm{mg} \mathrm{mL} \mathrm{m}^{-1}$ leaf extract) as $100 \%$, the relative radical scavenging capacity of $S$. torvum, S. virginianum, $S$. sisymbrifolium and S. nigrum were 109.8, 94.4, 97.1 and $93.9 \%$, respectively.
The $\mathrm{IC}_{50}$ value of fruit extract for $\mathrm{DPPH}$ radical scavenging capacity varied significantly in the fruits among the tested Solanum spp. and ranged from 27.78 to $33.11 \mathrm{mg} \mathrm{mL}{ }^{-1}$ fruit methanolic extract. As like the results of leaf extracts, S. virginianum, S. sisymbrifolium and $S$. nigrum fruit extracts shared statistically the lowest $\mathrm{IC}_{50}$ values as $27.90,28.35$ and $27.78 \mathrm{mg} \mathrm{mL}^{-1}$ fruit extract, respectively, and thus having highest radical scavenging capacity. In contrast, $\mathrm{IC}_{50}$ values of $S$. torvum $\left(31.05 \mathrm{mg} \mathrm{mL}^{-1}\right.$ ) and S. melongena (33.11) fruit extracts were maximum with identical statistical rank and thus having their lowest radical scavenging capacity. Considering the value of $\mathrm{IC}_{50}$ of $S$. melongena fruit (33.11 mg mL $\mathrm{m}^{-1}$ leaf extract) as $100 \%$, the relative $\mathrm{IC}_{50}$ values in S. torvum, S. virginianum, S. sisymbrifolium and S. nigrum were 93.7, 84.28, 85.62 and $83.89 \%$, respectively.

\section{Carotenoids content}

Total carotenoids content in leaves varied widely among the tested species of Solanum genus andits ranged from 0.027 to $0.370 \mathrm{mg} \mathrm{g}^{-1} \mathrm{FW}$ (Fig. 3). S. nigrum leaf showed the highest amount of carotenoids content as $0.370 \mathrm{mg} \mathrm{g}^{-1} \mathrm{FW}$ followed by the second highest in $S$. torvum $\left(0.266 \mathrm{mg} \mathrm{g}^{-1} \mathrm{FW}\right)$. The lowest value of carotenoids content was found in S. sisymbrifolium leaf $\left(0.027 \mathrm{mg} \mathrm{g}^{-1} \mathrm{FW}\right)$. The carotenoids content were intermediate in as $S$. virginianum $\left(0.190 \mathrm{mg} \mathrm{g}^{-1} \mathrm{FW}\right)$ and S. melongena $\left(0.244 \mathrm{mg} \mathrm{g}^{-1} \mathrm{FW}\right)$. S. torvum, $S$. virginianum, $S$. nigrum and $S$. sisymbrifolium had carotenoids content 111.1, 79.5, 154.3 and 11.3\%, respectively considering that had in S. melongina leaf as $100 \%$.

Carotenoids content in fruits varied widely among the tested genotypes and ranged from 0.0084 to $0.024 \mathrm{mg}$ $\mathrm{g}^{-1}$ FW (Fig. 3). S. torvum and S. virginianum fruits contained maximum amount of carotenoids $(0.024 \mathrm{mg}$ $\mathrm{g}^{-1} \mathrm{FW}$ in each), while. S. melongena fruit contained minimum amount of carotenoids $\left(0.0084 \mathrm{mg} \mathrm{g}^{-1} \mathrm{FW}\right)$. Carotenoids contents in fruits of S. nigrum $\left(0.011 \mathrm{mg} \mathrm{g}^{-1}\right.$ FW) and S. sisymbrifolium ( $\left.0.0085 \mathrm{mg} \mathrm{g}^{-1} \mathrm{FW}\right)$ were in between those. Considering the value of carotenoids content in S. melongena fruit as $100 \%$, the relative carotenoids content in S. torvum, S. virginianum, S. nigrum and S. sisymbrifolium were 298.0, 305.6, 145.7 and $106.7 \%$, respectively. 

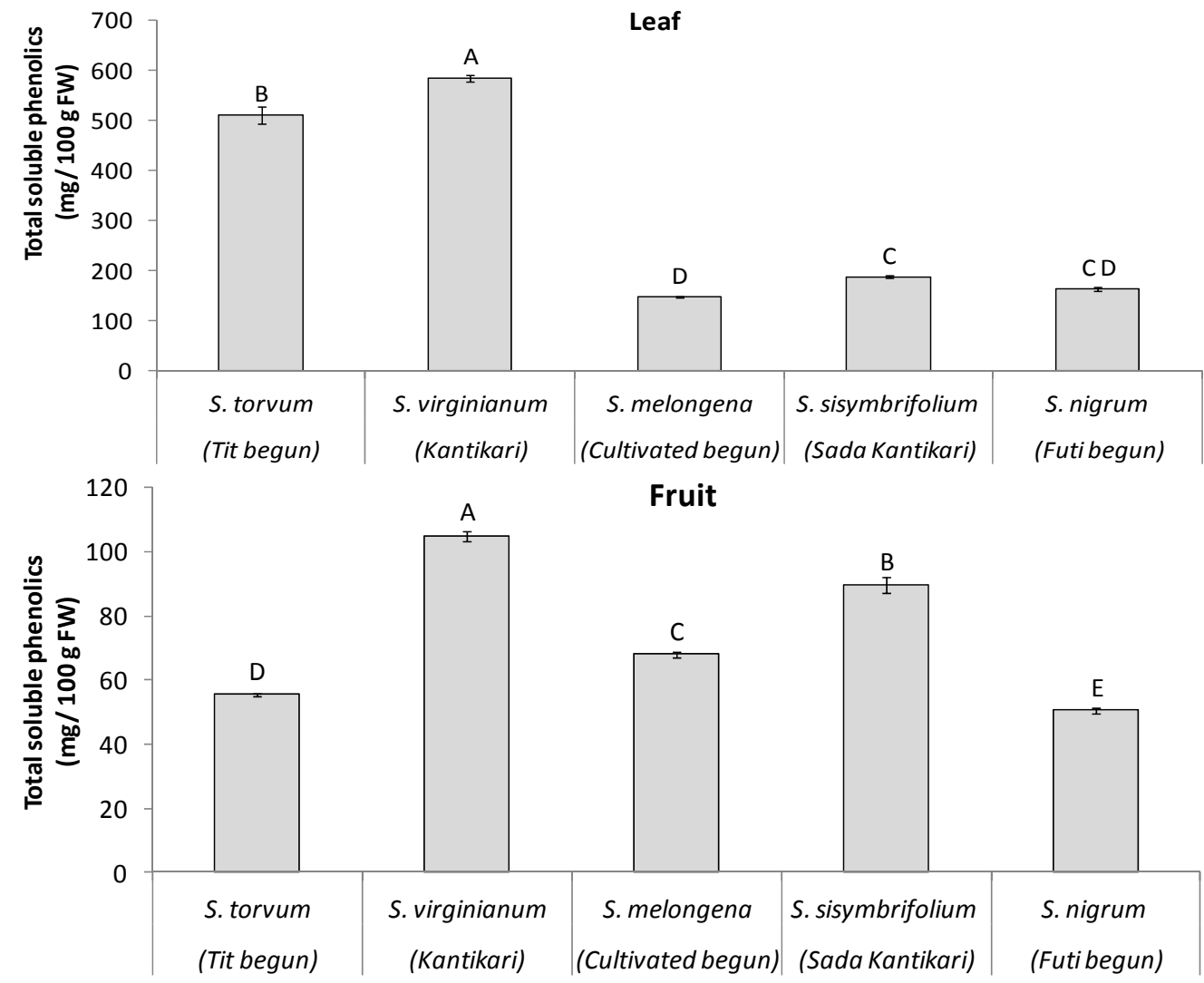

Fig. 1. Phenolics content in the leaf (above) and fruit (below) of eggplant and its four wild relatives. The amount of total phenolics content is expressed as mg gallic acid equivalent (GAE)/ $100 \mathrm{~g}$ of leaf fresh weight. Each data point is the average of three replicates \pm SEM. Bars sharing different letters are significantly different from each other at $\mathrm{P} \leq 0.05$.
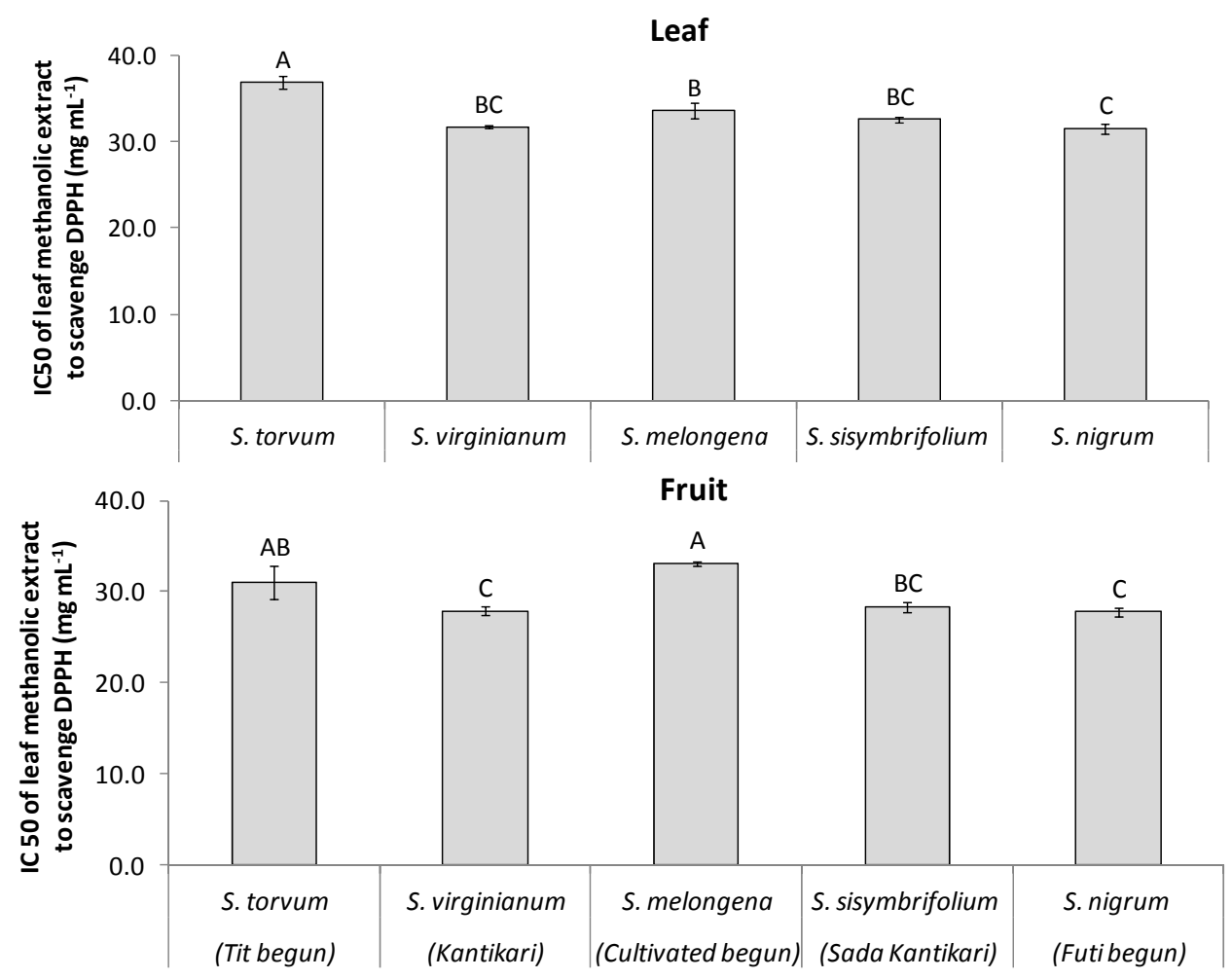

Fig. 2. $\mathrm{IC}_{50}$ values of the methanolic extracts of leaf (above) and fruit (below) of eggplant and its four wild relatives to scavenge DPPH radical. Each data point is the average of three replicates \pm SEM. Bars sharing different letters are significantly different from each other at $\mathrm{P} \leq 0.05$. 


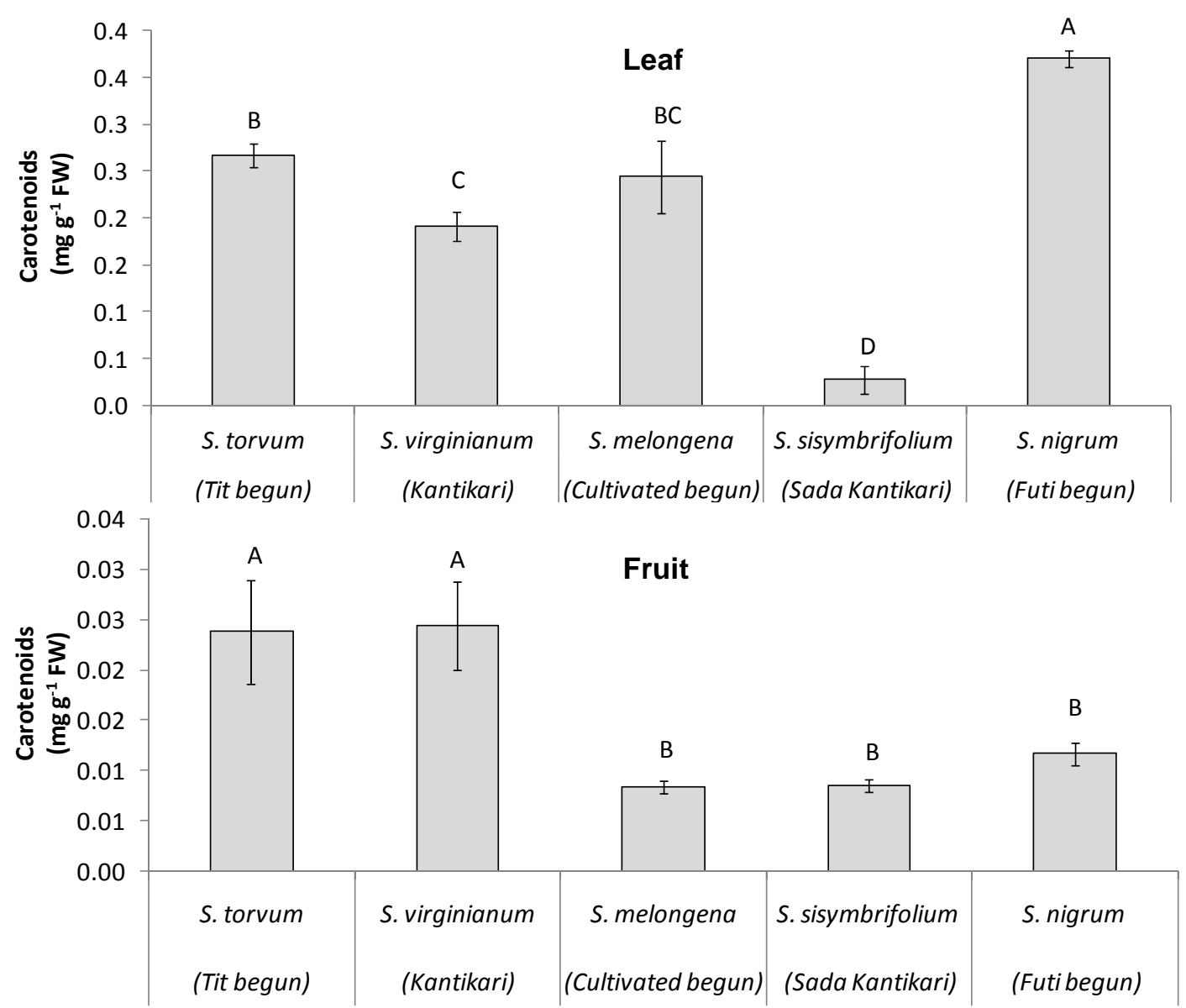

Fig. 3. Amount of total carotenoids content in leaf (above) and fruit (below) of eggplants and its four different wild relatives. Each data point is the average of three replicates \pm SEM. Bars sharing different letters are significantly different from each other at $\mathrm{P} \leq 0.05$

\section{Discussion}

Irrespective of genotypes leaves contained maximum phenolics compared to their fruits. Unique structure and a high tendency of phenolic compounds for metal chelation and their redox properties allow them to act as reducing agents, hydrogen donators, and singlet oxygen quenchers which could lead to anti-oxidant activity (Khoddami et al., 2013). Polyphenols are the large group of phytochemicals that are gaining acceptance as being responsible for the health benefits associated with fruits and vegetables. Because of their chemical structure, plant polyphenols can scavenge free radicals and inactive other pro-oxidants, and also interact with a number of biological relevance (Nisha et al., 2009). Phenolics in eggplant have been identified as major bioactive chemicals responsible for their antioxidative properties (Kwon et al., 2008). In this study, S. virginianum had been diagnosed to have highest amount of phenolics in both fruit and leaves compared to the other four genotypes. While S. torvum fruit has been reported to contain higher amount of phenolics as compared to that in S. menongena fruit (Kaur et al., 2014), our study showed higher amount of phenolics in S. melongena fruit as compared to the S. torvum. This may be due to the differences of varieties of $S$. melongena used in these two different experiments. For example, total phenolics of S. melongena was $271 \mathrm{mg}$ $\mathrm{GAE} / 100 \mathrm{~g}$ of $\mathrm{FW}$ in green variety and $394 \mathrm{mg}$ $\mathrm{GAE} / 100 \mathrm{~g}$ in violet one (Sharmin et al., 2011). However, our results of leaf phenolics content confirm the result of Kaur et al., 2014. Overall, cultivated genotypes had significantly lower leaf phenolics content than wild types. It is a well-established fact that presence of appreciable content of phenolics in food confers health promoting effects due to their antioxidant action. Natural phenolic compounds have been shown to possess antimicrobial, anti-cancerous, neuroprotective activities and help improve insulin secretion and manage obesity (Del Rio et al., 2010). This may adequately explain why certain landraces and wild relatives (e.g. S. torvum) are more popular than cultivated types in Southern and North-eastern states of India. S. torvum is a popular delicacy in Tamil Nadu too.

DPPH is a stable free radical and accepts an electron or hydrogen radical to become a stable diamagnetic molecule. The antioxidants in the sample scavenge this free radical. This method is widely used to evaluate the 
free radical scavenging capacity of natural antioxidants (Maharana et al., 2010). In this study $\mathrm{IC}_{50}$ of plant extracts to scavenge DPPH were assayed for the studied medicinal plants. The $\mathrm{IC}_{50}$ values are considered to be inversely proportional to the antioxidant activity of plant extract.

An eggplant genotype was compared with its four wild relatives (Fig. 2). DPPH radical scavenging activity was found highest in both leaf and fruit of S. nigrum, $S$. sisymbrifolium and S. virginianum. In contrast, S. torvum leaf and fruit showed the lowest capacity to scavenge DPPH. Free radicals, produced as a result of normal biochemical reactions in the body, are implicated in contributing to cancer, atherosclerosis, aging, immunesuppression, inflammation, ischemic heart disease, diabetes, hair loss, and neurodegenerative disorders such as Alzheimer's disease and Parkinson's disease (Beal, 1995).

Based on the absorbency value calculations were made using (Lichtenthaler, 1987) equation and the amount of carotenoids (sum of carotene and xanthophlyll) were estimated. In this study the highest carotenoids contents were detected in S. nigrum leaf as well as in S. torvum and $S$. virginianum fruits. Carotenoids are best recognized for their antioxidant capacity, especially in the membranes, since they are pigments located within membranes. Hydrogen peroxide, singlet oxygen, nitrogen oxides, superoxide anion, and other reactive oxygen species insulting the body from either endogenous or exogenous routes (and thus aggravating to a plethora of chronic human disease conditions) can be inactivated by carotenoids. Carotenoids are considered the most potent of biological quenchers of singlet oxygen (Paiva and Russell, 1999).

\section{Conclusion}

The leaf of S. virginianum acts as a good source of phenolics as it has the highest amount of phenolics than that in the fruits. S. virginianum, S. sisymbrifolium and S. nigrum leaf and fruit extracts showed the lowest $\mathrm{IC}_{50}$ values, and thus had the highest radical scavenging capacity while $S$. torvum and S. melongena fruit extracts had the lowest radical scavenging capacity. Coarotenoids contents were maximum in S. nigrum leaf extracts as well as in S. torvum and S. virginianum fruit extracts. Thus, S. virginianum leaves and fruits appear to be superior for their health beneficial biochemical constituents.

\section{References}

Albano, S.M. and Miguel, M.G., 2011. Biological activities of extracts of plants grown in Portugal. Ind. Crops Prod., 33: 338-343.

Beal, M.F., 1995. Aging, energy and oxidative stress in neurodegenerative diseases. Ann. Neurol., 38: 357-366.

Brand-Williams, W., Cuvelier, M.E. and Berset C.L.W.T., 1995. Use of a free radical method to evaluate antioxidant activity. Food Sci. Technol., 28(1): 25-30.

Del Rio, D., Costa, L.G., Lean, M.E. and Crozier, A., 2010. Polyphenols and health: What compounds are involved? Nutr. Metab. Cardiovasc. Dis., 20: 1-6.

Gupta, V.K., Aritra, S., Manish, T., Kashinath, B. and Amit, R., 2014. Phytochemical contents, antimicrobial and antioxidative activities of Solanum sisymbriifolium. J. App. Pharm Sci., 4 (3): 75-80.

Hao, D.C., Gu, X.J. and Xiao, P.G. 2015: High throughput sequencing in medicinal plant transcriptome studies. In: Medicinal Plants, 1st Edn. pp. 49-936. Woodhead Publishing.

Jaiswal, B.S., 2012. Solanum torvum: a review of its traditional uses, phytochemistry and pharmacology. Int. J. Pharm. Bio Sci., 3(4): 104-111.

Jennifer, M.E. and James, A.C., 1997. Black nightshades, Solanum nigrum L. and related species. Int. Plant Gen. Res. Ins., 2: 113.

Kaur, C., Nagal, S., Nishad, J. and Kumar, R. 2014. Evaluating eggplant (Solanum melongena L) genotypes for bioactive properties: A chemometric approach. Food Res. Int., 60: $205-211$.

Khoddami, A., Wilkes, M.A. and Roberts T.H., 2003. Techniques for analysis of phenolic compounds. Mol., 18: 2328-2375

Kwon, Y.I., Apostolidis, E. and Shetty, K., 2008. In vitro studies of eggplant (Solanum melongena) phenolics as inhibitors of key enzymes relevant for type 2 diabetes and hypertension. Bioresour. Technol., 99(8): 29818.

Lichtenthaler, H.K., 1987. Chlorophylls and Carotenoids: Pigments of Photosynthetic Biomembranes. Methods. Enzymol., 148: 350-382.

Maharana, L., Pattnaik, S., Kar D.M., Sahu, P.K. and Si, S.C., 2010. Anti-hyperglycemic potential of aqueous extract of leaves of Solanum nigrum Linn. Der Pharma Lettre 3: 333-345.

Nisha, P., Abdul Nazar, P. and Jayamurthy, P., 2009. A comparative study on antioxidant activities of different varieties of Solanum melongena.Food Chem. Toxicol., 47: 2640-2644.

Paiva, S.A.R. and Russell, R.M., 1999. $\beta$-carotene and other carotenoids as antioxidants. J. Am. Coll. Nutr., 18: 426433.

Sabir, S.M. and Rocha J.B.T., 2008. Antioxidant and hepatoprotective activity of aqueous extract of Solanum fastigiatum against paracetamol-induced liver damage in mice. J. Ethnopharmacol., 120: 226-232.

Saleem, T.M., Chetty, C.M., Ramkanth, S., Alagusundaram, M., Gnanaprakash, K., Rajan, V.T. and Angalaparameswari, S., 2009. Solanum nigrum Linn.-A review. Phcog. Rev. 3(6): 342 .

Sharmin, H., Nazma, S., Mohiduzzaman, M. and Banu C.P., 2011. Antioxidant capacity and total phenol content of commonly consumed selected vegetables of Bangladesh. Malaysian J. Nutri., 17(3): 377 - 388.

Sundar, S. and Pillai, Y.J.K., 2016. Pharmacognostic and physicochemical evaluation of Solanum virginianum L. leaves (solanaceae). Int. J. Pharma. Bio. Sci., 7(1): 40-41. 